Review

\title{
Augmentative Biological Control Using Parasitoids for Fruit Fly Management in Brazil
}

Flávio R. M. Garcia * and Marcelo P. Ricalde

Insect Ecology Lab, Department of Ecology, Zoology and Genetics, Institute of Biology, Federal University of Pelotas, P.O. Box 354, Pelotas, RS CEP 96010-900, Brazil;

E-Mail: flaviormg@hotmail.com

* Author to whom correspondence should be addressed; E-Mail: flavio.garcia@pq.cnpq.br; Tel.: +55-53-3275-7340.

Received: 16 October 2012; in revised form: 17 November 2012 / Accepted: 7 December 2012 / Published: 21 December 2012

Abstract: The history of classical biological control of fruit flies in Brazil includes two reported attempts in the past 70 years. The first occurred in 1937 when an African species of parasitoid larvae (Tetrastichus giffardianus) was introduced to control the Mediterranean fruit fly, Ceratitis capitata and other tephritids. The second occurred in September 1994 when the exotic parasitoid Diachasmimorpha longicaudata, originally from Gainesville, Florida, was introduced by a Brazilian agricultural corporation (EMBRAPA) to evaluate the parasitoid's potential for the biological control of Anastrepha spp. and Ceratitis capitata. Although there are numerous native Brazilian fruit fly parasitoids, mass rearing of these native species is difficult. Thus, D. longicaudata was chosen due to its specificity for the family Tephritidae and its ease of laboratory rearing. In this paper we review the literature on Brazilian fruit fly biological control and suggest that those tactics can be used on a large scale, together creating a biological barrier to the introduction of new fruit fly populations, reducing the source of outbreaks and the risk of species spread, while decreasing the use of insecticides on fruit destined for domestic and foreign markets.

Keywords: fruit flies; parasitoid; Diptera; Tephritidae; Braconidae 


\section{Introduction}

Approximately 70 species of fruit flies (Diptera: Tephritidae) are considered important agricultural pests [1]. These tephritids are mainly found in fruit crops including oranges, mangoes, apples and peaches, and fall into five genera: Anastrepha Schiner, Bactrocera Macquart, Ceratitis MacLeay, Dacus Fabricius and Rhagoletis Loew [1]. In Brazil, fruit fly larvae cause major production losses and limit fresh fruit exports mainly due to quarantine measures imposed by importing countries [2]. Economic losses due to fruit flies exceed two billion dollars worldwide [3]. In Brazil, more than 50\% of the economic losses have been recorded from the host plant families, Anacardiaceae, Myrtaceae, Passifloraceae and Sapotaceae [4]. Across South America, Anastrepha fraterculus Wiedemann (Diptera: Tephritidae) is of great economic importance across a variety of different environments. In Argentina, Uruguay and states of the southern and southeastern regions of Brazil (from Rio Grande do Sul to the south-central areas of Minas Gerais and Espirito Santo), this species is a serious pest, requiring the adoption of control measures to prevent economic losses [2].

Many natural enemies that are responsible for regulating populations, either naturally or by means of augmentative releases, have been identified [5]. The majority of fruit fly natural enemies in the Neotropical region belong to the families Braconidae (Opiinae), and Figitidae [6]. The most important biological control agents in Brazil belong to the genera Opius Wesmael, Utetes Foerster, Doryctobracon Szépligeti, Aganaspis Brèthes, Biosteres Ashmead and Diachasmimorpha Ashmead [5]. Augmentative biological control is a strategy whereby a natural enemy present in crops is augmented by individuals reared in the laboratory and released into the targeted area. The objective of an augmentative release is to cause rapid mortality in the host population [7]. Natural enemies are mass reared in specialized laboratories; therefore, this strategy relies on the ability to effectively mass produce natural enemies [7]. The timing of release is based on the biology of the target pest and the release is synchronized with periods when the pest is at the most susceptible stage [8].

Several countries produce and release parasitoids on a large scale, seeking to control and reduce populations to economically acceptable levels [9]. The first experiments with production-scale releases of braconids to suppress fruit flies were conducted in Hawaii [10]. Those promising results encouraged similar projects in Costa Rica, Mexico, Guatemala, United States (Florida) and Brazil [10,11]. The exotic parasitoid Diachasmimorpha longicaudata (Ashmead) (Hymenoptera: Braconidae) which has been used for biological control of Anastrepha populations, was originally collected from the Malaysia-Philippine region and is today considered one of the most important larval parasitoid biological control agents. This importance is based on its ease of rearing in the laboratory, the ability of D. longicaudata to quickly adapt to different environments, and its specificity of parasitism on tephritids and high capacity for parasitism on fruit flies $[12,13]$.

Although $D$. longicaudata has multiple fruit fly hosts and is easily reared in the laboratory, efforts to repeat the success of previous biological control campaigns have failed in the State of Rio Grande do Sul, where the climate is believed to have been the main limiting factor [13]. The potential of native parasitoids for the biological control of fruit flies is therefore being explored in this region [9]. A number of candidate species have been identified, including Opius sp. (Hymenoptera: Braconidae), Doryctobracon brasiliensis (Szépligeti) (Hymenoptera: Braconidae), Doryctobracon areolatus (Szépligeti) (Braconidae) and Aganaspis pelleranoi (Brèthes) (Hymenoptera: Figitidae), which in 
many situations can be found in orchards, together parasitizing up to $40 \%$ of flies [9]. Of these species, D. areolatus is the most abundant and frequent in Brazil [9].

The aim of this review is to discuss the history and current state of augmentative biological control of fruit flies in Brazil.

\section{Native Parasitoids}

Brazil is home to many species of native parasitoids (Table 1), including the efficient parasitoid D. areolatus which is widely distributed across the country. However, to date, the mass rearing of this and other native parasitoids has not been successful. Doryctobracon areolatus is only attracted to fruit fly larvae when they are associated with the fruit, thus increasing production costs and preventing their use in biological control in Brazil [14].

Nine native parasitoid species from the family Braconidae have been identified in several states of Brazil and other South American countries, but the most promising species for applicability in biological control programs include D. areolatus, Opius bellus Gahan and Utetes anastrephae (Viereck) (Braconidae), due mainly to their abundance in many regions [10]. In Bahia, five species of the fruit fly genera Anastrepha were reported: A. fraterculus (Wiedemann), Anastrepha sororcula Zucchi, Anastrepha obliqua (Macquart), Anastrepha. serpentina (Wiedemann) and Anastrepha bahiensis Lima. In addition, three Braconidae species were found: D. areolatus, Utetes anastrephae (Viereck) and Asobara anastrephae (Muesebeck) (Braconidae), with a parasitism index of $0.63 \%$ in Surinam cherry (Eugenia uniflora) and $8.97 \%$ in letterhout (Helicostylis tomentosa) [15]. In the Central Amazon region, Anastrepha pulchra Stone was collected from Mouriri collocarpa Ducke (Melastomataceae), in association with the parasitoid D. areolatus; Anastrepha atrigona Hendel in Strychnos jobertiana Baillon (Loganiaceae) and Pouteria durlandii (Standley) Baehni (Sapotaceae), in association with the parasitoids Opius bellus, Opius sp. (Braconidae), Aganaspis pelleranoi (Brèthes) (Figitidae) and Anastrepha coronilli Carrejo and González, in association with the parasitoid Aganaspis nordlanderi Wharton (Figitidae) [16]. In Santa Catarina, the main fruit fly parasitoids belong to three families: Braconidae, Diapriidae and Figitidae. Nora et al. [17] reported that D. areolatus (Szépligeti), D. brasiliensis Szépligeti, Opius bellus Gahan, 1930 and Opius. tomoplagiae (Lima), with $D$. areolatus were the most abundant. In that study, other parasitoids from the families Diapriidae, Eulophidae, Pteromalidae and Figitidae were obtained but not identified. Guimarães et al. [18] identified two Figitidae species, not previously recorded from this region, A. pelleranoi and Odontosema anastrephae Borgmeier (Figitidae). Leonel Jr. et al. [19] and Canal and Zucchi [6] have reported the occurrence of the braconids Microcrasis lonchaea (Lima) (Braconidae) and Utetes anastrephae (Braconidae). More recently, Garcia and Corseuil [20] recorded Trichopria anastrephae Lima (Diapriidae) and Lopeucoila anastrephae (Rhower) (Figitidae) in the region.

Recent studies of the biology of one of the most promising parasitoids, D. areolatus, demonstrated average parasitism rates of $A$. fraterculus of $54 \%$ could be achieved, with a range of $41.6 \%$ to $68.6 \%$. The development of the parasitoid from larva to adult took 25 days, with an average longevity of 16 days for males and 10 days for females and a sex ratio of 0.62 , demonstrating the species' capacity to parasitize $A$. fraterculus [21]. 
Table 1. List of parasitoids and their fruit fly hosts in Brazil.

\begin{tabular}{|c|c|c|c|}
\hline Species & Family of parasitoid & Host/s & State [Reference] \\
\hline $\begin{array}{l}\text { Aganaspis nordlanderi } \\
\text { Wharton }\end{array}$ & Figitidae & A. bahiensis, A. coronilli, A. strita Neosilba sp. & $\mathbf{A M}[16,18], \mathbf{S P}[22]$ \\
\hline $\begin{array}{l}\text { Aganaspis pelleranoi } \\
\text { (Bréthes) }\end{array}$ & Figitidae & $\begin{array}{l}\text { A. amita, } A \text {. bahiensis, } \text { A. fraterculus, } A \text {. atrigona, } A \text {. serpentina, } \\
\text { Ceratitis capitata, Neosilba sp., N. pendula, N. perezi, } \\
\text { C. capitata }\end{array}$ & $\begin{array}{l}\text { AM [16,18], BA [23], GO [24], PR [25], RJ [18], } \\
\mathbf{R S}[26-28], \mathbf{S C}[18,20,29], \mathbf{S P}[29,30]\end{array}$ \\
\hline $\begin{array}{l}\text { Asobara anastrephae } \\
\text { (Muessebeck) }\end{array}$ & Braconidae & Anastrepha sp., A. Bahiensis, A. obliqua, A. Zenildae & $\begin{array}{l}\text { AM [31,32], BA [15,33], GO [19,24], MS [34,35], } \\
\text { RN [36], SP [19] }\end{array}$ \\
\hline Asobara sp. & Braconidae & - & SP [37] \\
\hline Coptera haywardi Loiácono & Diapriidae & A. fraterculus, A. sororcula & RJ [38] \\
\hline $\begin{array}{l}\text { Dicerataspis flavipes } \\
\text { (Kieffer) }\end{array}$ & Figitidae & A. amita & $\mathbf{P A}[39], \mathbf{S P}[18]$ \\
\hline $\begin{array}{l}\text { Doryctobracon areolatus } \\
\text { (Szépligeti) }\end{array}$ & Braconidae & $\begin{array}{l}\text { A. amita, A. bahiensis, A. bistrigata, A. fraterculus, A. leptozona, } \\
\text { A. obliqua, A. pelleranoi, A. pulchra, A. pseudoparallela, } \\
\text { A. serpentina, A. sororcula, A. striata, A. zenildae, C. capitata, } \\
\text { R. pastranai, Neosilba } \mathrm{sp} \text {. }\end{array}$ & $\begin{array}{l}\text { AM }[16,29,31], \text { BA }[15,19,40], \text { ES }[19], \\
\text { GO [19,24], MA }[41], \text { MS }[34,42], \text { MG }[6,43], \\
\text { PA }[44], \text { PR, PI }[45],[9,25], \text { RN }[36], \\
\text { RS }[19,26-28], \text { RJ }[19,46], \text { SC }[17,19,20], \\
\text { SP }[19,37,47-50]\end{array}$ \\
\hline $\begin{array}{l}\text { Doryctobracon brasiliensis } \\
\text { (Szépligeti) }\end{array}$ & Braconidae & $\begin{array}{l}\text { A. amita, A. fraterculus, } A \text {. serpentina, } A \text {. pelleranoi, } \\
\text { A. sororcula, O. anastrephae, } R \text {. pastranai }\end{array}$ & $\begin{array}{l}\text { AM [29], PR [25], RS }[19,26], \mathbf{R J}[19,46], \\
\text { SC }[17,19,20], \mathbf{S P}[19,47,48,50]\end{array}$ \\
\hline $\begin{array}{l}\text { Doryctobracon fluminensis } \\
\text { Lima }\end{array}$ & Braconidae & $\begin{array}{l}\text { A. fraterculus, A. paralela, A. pseudoparallela, A. pickeli, } \\
\text { A. montei, Hexachaeta eximia }\end{array}$ & BA [51], MG [6,43], MS [34,35], RJ [29,52] \\
\hline Doryctobracon sp. & Braconidae & - & GO [24] \\
\hline Idiasta delicate & & Anastrepha sp. & AM [32] \\
\hline $\begin{array}{l}\text { Lopheucoila anastrephae } \\
\text { (Rhower) }\end{array}$ & & A. amita, A. Pseudoparallela, Neosilba sp., Lonchaea sp. & MS [22], SC [20], SP [29] \\
\hline $\begin{array}{l}\text { Lopheucoila truncicola } \\
\text { Weld. }\end{array}$ & Figitidae & - & $\mathbf{R J}[53]$ \\
\hline $\begin{array}{l}\text { Microcrasis lonchaeae } \\
\text { (Lima) }\end{array}$ & Braconidae & Rhagoletotrypeta pastranai, Neosilba pendula & SC [17], SP [29] \\
\hline
\end{tabular}


Table 1. Cont

\begin{tabular}{|c|c|c|c|}
\hline Species & Family of parasitoid & Host/s & State [Reference] \\
\hline Opius bellus Gahan & Braconidae & $\begin{array}{l}\text { A. fraterculus, A. pickeli, A. montei, A. obliqua, A. serpentina, } \\
\text { A. atrigona, C. capitata, Rhagoletis ferruginea, T. anastrephae, } \\
\text { R. pastranai }\end{array}$ & $\begin{array}{l}\text { AM }[16,31], \text { GO }[24], \text { MS }[34,42], \text { PA }[44] \\
\text { RS }[19,26-29], \text { RJ }[19,46], \text { SC }[17,19,20], \\
\text { SP }[19,29,43,47,49]\end{array}$ \\
\hline Opius bucki Lima & Braconidae & Tomoplagia rudolphi & MG [29], RS [52] \\
\hline Opius itatiayensis Lima & Braconidae & Tomoplagia sp. & RJ [52] \\
\hline Opius tomoplagiae Lima & Braconidae & Tomoplagia rudolphi & MG [52], PR [29], RJ [52], SP [29] \\
\hline Opius sp. & Braconidae & Anastrepha sp, A. distincta, A. atrigona, A. leptozona, A. obliqua & $\begin{array}{l}\text { AM [16,31], BA [3], GO [24], MS [34], } \\
\text { PA [29,44], PI [45], RJ [19,29], SC [17,19,20], } \\
\text { SP [19] }\end{array}$ \\
\hline $\begin{array}{l}\text { Odontosema albinerve } \\
\text { Kieffer }\end{array}$ & Figitidae & - & PA [39] \\
\hline $\begin{array}{l}\text { Odontosema anastrephae } \\
\text { Borgmeier }\end{array}$ & Figitidae & A. fraterculus & AM [18], MS [18], RS [26], SC [18,20], SP [54] \\
\hline Trichopria anastrephae Lima & Diapriidae & A. fraterculus, A. serpentina & $\begin{array}{l}\text { GO [55], MG [56], RS [27], RJ [29,57,58], } \\
\text { SC [20] }\end{array}$ \\
\hline $\begin{array}{l}\text { Tropideucoila angrensis } \\
\text { Borgmeier }\end{array}$ & Figitidae & - & $\mathbf{R J}[57]$ \\
\hline $\begin{array}{l}\text { Tropideucoila rufipes } \\
\text { Ashmead }\end{array}$ & Figitidae & - & MT [59] \\
\hline Tropideucoila weldi Lima & Figitidae & Neosilba pendula & RJ [54] \\
\hline Trybliographa sp. & Figitidae & Anastrepha spp., Neosilba spp. & SP [18] \\
\hline Utetes anastrephae (Viereck) & Braconidae & $\begin{array}{l}\text { A. amita, A. fraterculus, A. obliqua, A. sororcula, A. manihoti, } \\
\text { R. pastranai, Neosilba } \mathrm{sp.}\end{array}$ & $\begin{array}{l}\text { AM [31], BA [15,19,40,60], MS [34], MG [6] } \\
\text { PA [44], PR [25], RS }[19,26], \mathbf{R J}[19,46], \\
\text { SC }[17,19,20], \text { SP }[43,47,48,60]\end{array}$ \\
\hline
\end{tabular}

* AM = Amazonas, AP = Amapá, BA = Bahia, ES = Espírito Santo, GO = Goiás, MA = Maranhão, MG = Minas Gerais, MS = Mato Grosso do Sul, MT = Mato Grosso, $\mathrm{PA}=$ Pará, PI = Piauí, PR = Paraná, RN = Rio Grande do Norte, RJ = Rio de Janeiro, SC = Santa Catarina, SP = São Paulo. 


\section{Introduced Parasitoids}

\subsection{Tetrastichus giffardianus}

Two classical biological control programs for the control of fruit flies have been reported in Brazil, and which preceded any form of augmentative release. The first occurred in 1937 when the African larval parasitoid Tetrastichus giffardianus Silvestri (Hymenoptera: Eulophidae) was introduced to control Ceratitis capitata Wiedemann and other tephritids. The second occurred in 1994 when the Brazilian agricultural corporation Embrapa Cassava and Tropical Fruits ("Embrapa Mandioca e Fruticultura Tropical") introduced the exotic parasitoid Diachasmimorpha longicaudata (Ashmead) to Brazil from Gainesville, Florida, to evaluate the parasitoid's potential for the biological control of fruit flies of the genus Anastrepha and C. capitata [11,61-63].

The use of $T$. giffardianus for the augmentative biological control of fruit flies has advantages and disadvantages. Advantages include the gregarious nature of this species, the high proportion of females among the offspring, and females which penetrate the fruit to lay eggs in the larvae, thus directly attacking the larvae that often escape from Opiinae parasitism, of which the larger fruit of the latter may be an issue, due to difficulties of the parasitoids ovipositor reaching deeply entrenched larvae [64]. Additionally, during the mass-rearing process, the time lag between the emergence of the flies and that of the parasitoids eliminates the problem of releasing these flies into the environment [63]. Disadvantages that may possibly limit the applicability of this parasitoid include its relatively low rate of parasitism and short life span when released. However, the low rate of parasitism would be offset by the high gross reproductive rate because more than one parasitoid is produced by the host. This parasitoid was introduced in the state of São Paulo, and 60 years later, it is no longer found in the southeast region. However, it persists in the states of Bahia, Rio Grande do Norte and Ceará, likely due to the warmer climate [63].

\subsection{Diachasmimorpha longicaudata}

Four years after D. longicaudata's introduction into Bahia, Matrangolo et al. [65] conducted field surveys to evaluate the parasitoid's establishment and association with several species of fruiting trees including: the common guava, Psidium guajava L. (Mirtaceae); Surinam cherry, Eugenia uniflora L. (Mirtaceae); starfruit, Averrhoa carambola L. (Oxalidacea); and mango, Magnifica indica Linnaeus (Anacardiaceae). Subsequently, the exotic D. longicaudata was mass reared in the laboratory and released weekly on all of the aforementioned fruiting trees but at low levels of approximately 1,000 parasitoids. Surveys prior to these releases in a multi-species orchard revealed the presence of a number of native hymenopterans, including D. areolatus, Utetes anastrephae, Opius spp., Asobara anastrephae (Muesebeck) and Aganaspis pelleranoi. Surveys conducted after the release of $D$. longicaudata showed that these native species persisted and that although interspecific competition for oviposition sites existed, no loss of biodiversity was observed [66]. Diachasmimorpha longicaudata was detected 17 months post release from starfruit, guava and other environments, such as a hybrid species of umbu-caja, but was not recorded during the surveys conducted in 2004 and 2005 [66]. The ability of D. longicaudata to adapt to semi-arid (São Francisco water basin, State of Bahia, Brazil) and Amazonian (Oiapoque, State of Amapa, Brazil) ecosystems demonstrates this species' capacity to 
parasitize hosts and complete its life cycle in a variety of different environments. Although the Amazon in particular presents complex ecosystems and interspecific competition with native species, this parasitoid was able to readily adapt [67].

Approximately 34,000 pairs of $D$. longicaudata were released on fifteen occasions over seven weeks in commercial guava orchards in the semi-arid northern region of Minas Gerais. Seven days post release, a survey recovered a total of 37 specimens of D. longicaudata, indicating that the species completed its life cycle in the local conditions and has the capacity to establish in the region $[64,68,69]$.

In Botucatu, State of São Paulo, D. longicaudata were released in areas of riparian forest to suppress the density of Anastrepha fraterculus impacting nearby citrus orchards [70]. The release was timed to occur between insecticide applications, to minimize any effects of spray drift on released parasitoids. A total of 14 releases occurred between April and October, and a total of 560,000 parasitoids were released, which resulted in a $30 \%$ reduction in $A$. fraterculus infestations and a consequent reduction in the application of insecticides [70].

\section{Mass Rearing and Release Requirements for Parasitoids in Brazil}

Although Brazil has a diverse number of native fruit fly parasitoid species, difficulties have been found in the mass rearing of these species. Such difficulties led to the introduction of $D$. longicaudata. This parasitoid has been used because of its host specificity for the family Tephritidae and its ease of laboratory rearing. The parasitoid $D$. longicaudata originates from Indo-Australia where the natural hosts are flies of the genus Bactrocera [71].

When searching for a host, $D$. longicaudata is attracted to volatile substances released by the fruit and the vibrations produced by the fly larvae during feeding, mainly in fallen fruits rotting on the ground $[72,73]$. The average life cycle for $D$. longicaudata reared in the laboratory at a temperature of $22-26^{\circ} \mathrm{C}$, and 14-hour photoperiod on C. capitata larvae ranges from 14 to 16 days [73]. The pre-oviposition period is two days, and the oviposition period is 28-30 days. In mass-rearing facilities in the State of São Paulo, an average parasitism rate of $46.1 \%$ is achieved, with a ratio of three females to one male [73].

In Brazil, in studies with rearing cages placed under natural (outdoor) conditions, D. longicaudata was more efficient compared to other parasitoids and, in some cases, reached parasitism levels of $91.42 \%$. This efficiency is true when reared on both $C$. capitata and Anastrepha sp. [14,67,74]. In the field, a significant reduction (40.0\%-95.0\%) was observed in trapped $A$. suspensa flies when the parasitoid was released at inundation [68,75-79].

Although $D$. longicaudata attacks both $C$. capitata, and A. fraterculus, when these species are present together in the same environment, the parasitoid demonstrates a preference for $A$. fraterculus [68].

In Brazil, Diachasmimorpha longicaudata is mass-reared in cages containing water, food (sugar and soy protein) and a means for oviposition (papaya fruit and artificial plastic fruit, although the flies will also oviposit through the cage screen) (Figure 1) [61]. The eggs are collected with a paintbrush, and the larvae are subsequently reared on an artificial diet. When the larvae reach third instar, they are exposed to adult parasitoids in a nursery container, simulating an infested fruit to facilitate access to the larvae. Adult parasitoids are fed an artificial diet $(120 \mathrm{~mL}$ warm water, $0.8 \mathrm{~g}$ agar, $0.05 \mathrm{~g}$ ascorbic 
acid, $0.005 \mathrm{~g}$ Nipagin and $120 \mathrm{~mL}$ honey) and water. After 24 hours, the larvae are placed in containers containing vermiculite for pupation and adult emergence [61]. The parasitoid offspring are removed from the emergent cages with the aid of a vacuum adapted to provide weak suction [61].

Figure 1. C. capitata in a rearing cage, water; artificial fruit; adult food; papaya.

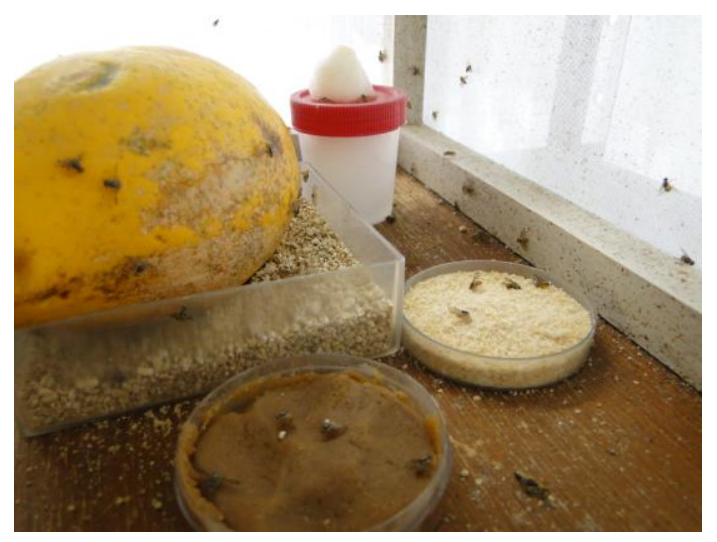

Rearing of $D$. areolatus in Brazil is done in cages of varying sizes and always uses A. fraterculus as the host. The diet for this parasitoid is composed of honey, distilled water, agar, ascorbic acid, and sodium benzoate or honey and water. Mass production of this parasitoid has been unsuccessful because it is a species with a high risk of death due to behavioral attributes and genetic degeneration in the colonization process $[14,21,80]$. Additionally, the parasitoid $T$. giffardianus is a potential candidate for biological control in Brazil, but there is a lack of information about diet, mass-rearing methods and economics. On the other hand, D. longicaudata is easily reared and is the species most often utilized in Brazil. This species is primarily reared in larval $C$. capitata because they possess sterile lines, and the adults also utilize a diet based on honey, distilled water, agar, ascorbic acid and sodium benzoate (Table 2) $[14,69,81,82]$.

Table 2. Comparison between the rearing techniques of Doryctobracon areolatus and Diachasmimorpha longicaudata in Brazil.

\begin{tabular}{|c|c|c|c|c|c|}
\hline \multirow{2}{*}{$\begin{array}{l}\text { Parasitoids } \\
\text { Authors }\end{array}$} & \multicolumn{2}{|c|}{ Doryctobracon areolatus } & \multicolumn{3}{|c|}{ Diachasmimorpha longicaudata } \\
\hline & Costa et al. [80] & Nunes et al. [21] & Walder et al. [81] & $\begin{array}{l}\text { Alvarenga et al. } \\
\text { [69] }\end{array}$ & Costa et al. [82] \\
\hline Host & A. fraterculus & A. fraterculus & C. capitata & C. capitata & C. capitata \\
\hline Cages $(\mathrm{cm})$ & $30 \times 50 \times 30$ & $11 \times 12 \times 19$ & $50 \times 50 \times 30$ & $15 \times 12$ & $50 \times 50 \times 30$ \\
\hline Diet & $\begin{array}{l}\text { Honey, distilled } \\
\text { water }\end{array}$ & Honey & $\begin{array}{l}\text { Honey, distilled } \\
\text { water, agar, } \\
\text { ascorbic acid and } \\
\text { sodium benzoate }\end{array}$ & $\begin{array}{l}\text { Honey, distilled } \\
\text { water }\end{array}$ & $\begin{array}{l}\text { Honey, distilled } \\
\text { water, agar, } \\
\text { ascorbic acid and } \\
\text { Nipagin }\end{array}$ \\
\hline Temperature $\left({ }^{\circ} \mathrm{C}\right)$ & $25 \pm 2$ & $25 \pm 2$ & $26 \pm 2$ & $26 \pm 2$ & $26 \pm 2$ \\
\hline Humidity $(\%)$ & $70 \pm 10$ & $70 \pm 10$ & $75 \pm 5$ & $65 \pm 10$ & $70 \pm 10$ \\
\hline Photophase (h) & 4 & 12 & 14 & 14 & 14 \\
\hline Sex ratio & 0.62 & $0.62 \pm 0.09$ & $\longrightarrow$ & $\longrightarrow$ & 0.57 \\
\hline $\begin{array}{l}\text { mean longevity } \\
\text { (days) }\end{array}$ & & $\begin{array}{l}16.36 \pm 3.62\left(\delta^{\lambda}\right) \\
\text { and } 10.24 \pm 1.71 \\
(q)\end{array}$ & & & \\
\hline $\begin{array}{l}\text { mean parasitism } \\
\text { rate }(\%)\end{array}$ & & $53.50 \pm 8.93$ & $46.1 \%$ & & \\
\hline
\end{tabular}


In Brazil, there are few publications on biological parameters of parasitoids of fruit flies reared in the laboratory, which makes it difficult to determine the best technique. However, it is known that the mass-rearing technique used by the Center for Nuclear Energy in Agriculture, University of São Paulo (CENA/USP) produced more than 150 million specimens of D. longicaudata in Brazil from January 1995 to October 2001 [81].

\section{Bio-Fabrication}

Today, the biological control of fruit flies in programs across Brazil is largely based on the augmentative release of introduced parasitoids to achieve effective suppression of pest fly populations on an area-wide basis [62]. Consequently, for these programs to be successful, a large number of agents must be available. In Brazil, bio-factories mass produce and commercially provide a range of biological control agents. The bio-factory Moscamed Brazil was created in Juazeiro, State of Bahia, in 2005, with the main objective of producing sterile insects for the release and eradication of C. capitata. This factory has a production capacity of 100 million sterile males per week. In addition, the factory also produces 10 million D. longicaudata/week for the biological control of Anastrepha spp. and C. capitata [14]. The factory was made possible through investments by federal and state governments and international partnerships (International Atomic Energy Agency-IAEA).

\section{Conclusions}

In Brazil, the most effective parasitoid for use in augmentative biological control programs for Anastrepha spp. and C. capitata is D. longicaudata. This species is preferred mainly due to its ease of rearing and high parasitism levels. Successful control programs with this parasitoid require repeated releases until the parasitoid becomes fully established in the area [62].

Worldwide, D. longicaudata is an important parasitoid of fruit flies for several reasons including its ease of rearing, intensive foraging and high activity of resource exploitation by females. However, several studies have shown low indices of parasitism and recovery of specimens of $D$. longicaudata released in Brazil. Evidence from these studies suggests that the removal of fruit from the field during sampling may have reduced the susceptibility period of larvae to the parasitoid, therefore generating an underestimation of the parasitism index. Moreover, D. longicaudata also demonstrates a low tolerance to cold, inferred from its decreased effectiveness during the winter in southern Brazilian states, despite continued effectiveness in warmer regions of the country [63].

Studies that seek alternatives to using exotic introduced parasitoids in Brazil are greatly lacking, with more technically and economically feasible efforts required for the development of research aimed at the mass rearing of native parasitoids, particularly D. areolatus. Another parasitoid that requires research attention for its potential against a range of flies in Brazil is Fopius arisanus (Sonan). This parasitoid develops in the egg and early larval instar of fruit flies, and emerges from the pupae [83] and has surpassed D. longicaudata in all competition studies [84-86].

The successful use of parasitoids for the suppression of fruit fly populations depends on studies that evaluate the behavior of these insects and the use of such methods in conjunction with other area-wide control techniques on an integrated pest management basis (IPM). In Brazil, biological control and the sterile insect technique (SIT) are expected to be used across large areas, suppressing fly 
populations, reducing the source of infestations and the risk of spread of pest species, reducing the use of insecticides in fruit destined for domestic and foreign markets, and ultimately creating a biological barrier to fruit fly incursions in major horticultural regions.

The augmentative biological control of fruit flies is now a reality in Brazil, along with other biological control techniques, including SIT, which, when used in combination, is believed capable of increasing the overall efficiency and effectiveness of control of pest fruit flies in Brazil [87].

\section{Acknowledgments}

We thank the National Council of Technological and Scientific Development of Brazil $(\mathrm{CNPq})$ for the Scholarship of Research Productivity.

\section{References}

1. Garcia, F.R.M. Fruit fly: Biological and ecological aspects. In Current Trends in Fruit Flies Control on Perennial Crops and Research Prospects; Bandeira, R.R., Ed.; Transworld Research Network: Kerala, India, 2009; pp. 1-35.

2. Malavasi, A.; Zucchi, R.A.; Sugayama, R.L. Biogeografia. In Moscas-das-frutas de importância econômica no Brasil: conhecimento básico e aplicado (in Portuguese); Malavasi, A., Zuchhi, R.A., Eds.; Holos: Ribeirão Preto, Brazil, 2000; pp. 93-98.

3. Zucchi, R.A.; Malavasi, A.; Nascimento, A.S.; Walder, J.M.M. Prejuízos das moscas-das-frutas na exportação de citros (in Portuguese). Visão Agrícola 2004, 2, 73-77.

4. Zucchi, R.A. Anastrepha species and their hosts plants. Fruit flies in Brazil. 2008. Accessed online: http://www.lea.esalq.usp.br/anastrepha/edita_infos.htm (accessed on 30 November 2011).

5. Wharton, R.A. Subfamily Opiinae. In Manual of the New World genera of the Family Braconidae (Hymenoptera); Wharton, R.A., Marsh, P.M., Sharkey, M.J., Eds.; Allen Press: Lawrence, KS, USA, 1997; pp.379-395.

6. Canal, D.N.A.; Zucchi, R.A. Parasitoides, Braconidae, In Moscas-das-frutas de importância econômica no Brasil: conhecimento básico e aplicado (in Portuguese); Malavasi, A., Zuchhi, R.A., Eds.; Holos: Ribeirão Preto, Brazil, 2000; pp.119-126.

7. Parra, J.R.P.; Botelho, P.S.M.; Corrêa-Ferreira, B.S.; Bento, J.M.S. Controle biológico: Uma visão inter e multidisciplinar. In Controle biológico no Brasil (in Portuguese); Parra, J.R.P., Botelho, P.S.M., Corrêa-Ferreira, B.S., Bento, J.M.S., Eds.; Manole: São Paulo, Brazil, 2002; pp. 125-137.

8. Uchôa, M.A. Fruit Flies (Diptera:Tephritoidea): Biology, host plants, natural enemies, and the implications to their natural control. In Integrated Pest Management and Pest Control, Current and Future Tactics; Soloneski, S., Larramendy, M.L., Eds.; InTech: Rijeka, Croatia, 2012; pp. 271-300.

9. Nava, D.E. Controle Biológico de Insetos-praga em Frutíferas de Clima Temperado: Uma Opção Viável, Mas Desafiadora (in Portuguese); Embrapa: Pelotas, Brazil, 2007.

10. Ovruski, S.; Aluja, M.; Sivinski, J.; Wharton, R. Hymenopteran parasitoids on fruit-infesting Tephritidae (Diptera) in Latin America and the southern United States: Diversity, distribution, taxonomic status and their use in fruit fly biological control. Integr. Pest Manag. Rev. 2000, 5, 81-107. 
11. Nascimento, A.S.; Carvalho, R.S.; Mendonça, M.C.; Sobrinho, R.B. Pragas e seu controle. In $A$ Cultura da Mangueira (in Portuguese); Genú, P.J.C., Pinto, A.C.Q., Eds.; Embrapa: Brasília, Brazil, 2002; pp. 279-297.

12. Ovruski, S.M.; Bezdjian, L.P.; van Nieuwenhove, G.A.; Albornoz-Medina, P.; Schliserman, P. Host Preference by Diachasmimorpha longicaudata (Hymenoptera: Braconidae) Reared on Larvae of Anastrepha fraterculus and Ceratitis capitata (Diptera: Tephritidae). Flo. Entomol. 2011, 94, 195-200.

13. López, M.; Aluja, M.; Sivinski, J. Hymenopterous larval-pupal and pupal parasitoids of Anastrepha flies (Diptera: Tephritidae) in Mexico. Bio. Contr. 1999, 15, 119-129.

14. Paranhos, B.A.J. Biofábrica Moscamed Brasil,Tecnologia Ambientalmente Segura no Combate às Pragas. In Proceedings of the 2nd Symposium of mango of Vale do São Franscisco, Salvador, Bahia, Brazil, 9 August 2007.

15. Bittencourt, M.A.L.; Da Silva, A.C.M.; Silva, V.E.S.; Bomfim, Z.V.; Guimarães, J.A.; de Souza Filho, M.F.; Araújo, E.L. Moscas-das-Frutas (Diptera: Tephritidae) e seus Parasitoides (Hymenoptera: Braconidae) Associados às Plantas Hospedeiras no Sul da Bahia. Neotrop Entomol. 2011, 40, 405-406.

16. Ronchi-Teles, B.; Dutra, V.S.; Costa, A.P.T.; Aguiar-Menezes, E.D.L.; Mesquita, A.C.A.; Silva, J.G. Natural host plants and native parasitoids associated with Anastrepha pulchra and other Anastrepha species (Diptera: Tephritidae) in Central Amazon, Brazil. Flo. Entomol. 2011, 94, 347-349.

17. Nora, I.; Hickel, E.R.; Prando, H.F. Santa Catarina. In Moscas-das-frutas de importância econômica no Brasil: conhecimento básico e aplicado (in Portuguese); Malavasi, A., Zuchhi, R.A., Eds.; Holos: Ribeirão Preto, Brazil, 2000; pp. 271-275.

18. Guimarães, J.A.; Diaz, N.B.; Zucchi, R.A. Parasitóides — Figitidae (Eucoilinae). In Moscas-dasfrutas de importância econômica no Brasil: conhecimento básico e aplicado (in Portuguese); Malavasi, A., Zuchhi, R.A., Eds.; Holos: Ribeirão Preto, Brazil, 2000; pp. 127-134.

19. Leonel Jr., F.L.; Zucchi, R.A.; Wharton, R.A. Distribution and tephritid hosts (Diptera) of braconid parasitoids (Hymenoptera) in Brazil. Int. J. Pest Manag. 1995, 41, 208-213.

20. Garcia, F.R.M.; Corseuil, E. Native hymenopteran parasitoids associated with fruit flies (Diptera: Tephritidae) in Santa Catarina State, Brazil. Flo. Entomol. 2004, 8, 517-521.

21. Nunes, A.M.; Nava, D.E.; Müller, F.A.; Gonçalves, R. da S.; Garcia, M.S. Biology and parasitic potential of Doryctobracon areolatus on Anastrepha fraterculus larvae. Pesq. Agropec. Bras. 2012, 46, 669-671.

22. Guimarães, J.A; Perioto, N.W. Primeira ocorrência de Aganaspis nordlanderi Wharton, 1998 (Hymenoptera, Figitidae: Eucolinae) no Brasil. Arq. Inst. Biol. 1998, 65, 44-45.

23. Matrangolo, W.J.R.; Nascimento, A.S.; Carvalho, R.S. Criação em laboratório de Aganaspis pelleranoi (Hymenoptera: Eucoilidae), parasitoide de moscas-das-frutas (Diptera: Tephritidae). In Proceedings of the 16th Brazilian Congress of Entomology, Salvador, Bahia, Brazil, 14-16 April, 1997.

24. Veloso, V.R.S; Zucchi, R.A.; Canal, D.N.A.; Sugayama, R.L. Espécies de parasitoides (Hym., Braconidae) de moscas de las frutas (Dip., Tephritidae) em el Estado de Goiás, Brasil, (in 
Spanish). In Proceedings of 2nd Meeting of the Working Group on Fruit Flies of the Western Hemisphere, Viña del Mar, Chile, 8 November 1996.

25. Menezes, A.O., Jr.; Bizeti, H.S.; Araujo, E.L. Parasitoides (Hymenoptera: Braconidae; Eucoilidae) associados às moscas-das-frutas (Diptera: Tephritidae; Lonchaeidae) na região Norte do Estado do Paraná. In Proceedings of the 16th Brazilian Congress of Entomology, Salvador, Bahia, Brazil, March 7th, 1997.

26. Salles, L.A.B. Parasitismo de Anastrepha fraterculus (Wied.) (Diptera: Tephritidae) por Hymenoptera, na região de Pelotas, RS (in Portuguese). Pesq. Agropec. Bras. 1996, 31, 769-774.

27. Cruz, P.P.; Neutzling, A.S.; Garcia, F.R.M. Primeiro registro de Trichopria anastrephae, parasitoide de mosca-das-frutas, no Rio Grande do Sul (in Portuguese). Ciênc. Rural 2011, 41, 1297-1299.

28. Nunes, A.M.; Müller, F.A.; Gonçalves, R.S.; Garcia, M.S.; Costa, V.A.; Nava, D.E. Moscas frugívoras e seus parasitoides nos municípios de Pelotas e Capão do Leão, Rio Grande do Sul, Brasil (in Portuguese). Ciênc. Rural 2012, 42, 6-12.

29. De Santis, L. Catalogo de Los himenopteros brasileños de la Serie Parasitica; Incluyendo Berthyloidea (in Portuguese); Editora UFPR: Curitiba, Brazil, 1980.

30. Dettmer, H. Ganaspis carvalhoi n. sp. (Hym. Cynipidae) um novo parasita da mosca-das-frutas (Anastrepha fraterculus Wied.) (in Portuguese). Bol. Biol. 1929, 16, 70-74.

31. Canal, D.N.A.; Zucchi, R.A.; Silva, N.M.; Silveira Neto, S. Análise faunística dos parasitoides (Hymenoptera: Braconidae) de Anastrepha (Dip., Tephritidae) em Manaus e Iranduba, Estado do Amazonas (in Portuguese). Acta Amazon 1995, 25, 235-246.

32. Costa, S.G.M.; Querino, R.B.; Ronchi-Teles, B.; Penteado-Dias, A.M.M.; Zucchi, R.A. Parasitoid diversity (Hymenoptera: Braconidae and Figitidae) on frugivorous larvae (Diptera: Tephritidae and Lonchaeidae) at Adolpho Ducke Forest Reserve, Central Amazon Region, Manaus, Brazil. Braz. J. Biol. 2009, 69, 363-337.

33. Silva, J.G.; Dutra, V.S.; Santos, M.S.; Silva, N.M.O.; Vidal, D.B.; Nink, R.A.; Guimarães, J.A.; Araújo, E.L. Diversity of Anastrepha spp. (Diptera: Tephritidae) and associated braconid parasitoids from native and exotic hosts in Southern Bahia, Brazil. Environ. Entomol. 2010, 39, $1457-1465$.

34. Uchôa, M.A.; Oliveira, I.; Molina, R.M.S.; Canal, D.N.A.; Zucchi, R.A. Primeiro registro de parasitoides (Hym.: Braconidae) de moscas-das-frutas (Diptera: Tephritidae) em Mato Grosso do Sul. (in Portuguese). In Proceedings of the 5th Brazilian Symposium of Biological Control, Foz do Iguassú, Paraná, Brazil, 14 June 1996.

35. Uchôa, M.A.; Molina, R.M.S.; Oliveira, I.; Zucchi, R.A.; Canal N.A.; Díaz, N.B. Larval endoparasitoids (Hyemnoptera) of frugivorous flies (Diptera, Tephritoidea) reared from fruits of the cerrado of the State of Mato Grosso do Sul, Brazil. Rev. Bras. Entomol. 2003, 47, 181-186.

36. Araújo, E.L.; Zucchi, R.A.; Malavasi, A.; Negreiros, J. Levantamento de moscas-das-frutas do gênero Anastrepha Schiner, 1868 (Dip., Tephritidae) nos municípios de Mossoró e Assu—RN (in Portuguese). Rev. Agric. 1996, 71, 225-232.

37. Raga, A.; Souza Filho, M.F.; Sato, M.E.; Arthur, V.; Martins, A.L.M. Incidencia de moscas de la fruta em variedades de café (Coffea spp.) em el Estado de São Paulo, Brasil, (in Spanish). 
In Proceedings the 2nd Meeting of the Working Group on Fruit Flies of the Western Hemisphere, Viña del Mar, Chile, 8 November 1996.

38. Aguiar-Menezes, E.L.; Menezes, E.B.; Loiacono, M.S. First record of Coptera haywardi Loiácono (Hymenoptera: Diapriidae) as a parasitoid of fruit-infesting Tephritidae (Diptera) in Brazil. Neotropic. Entomol. 2003, 32, 355-358.

39. Kieffer, J.J. Description de noveaux cynipides zoophages. Bull. Soc. Hist. Nat. Metz. 1909, 3, 57-96.

40. Carvalho, R.S.; Matrangolo, W.J.R.; Nascimento, A.S.; Melo, E.D. Influência do estádio fenológico de frutos de pitanga na presença de parasitoides de moscas-das-frutas, Salvador, Bahia, Brazil (in Portuguese). In Proceedings the 16th Brazilian Congress of Entomology, Salvador, Bahia, Brazil, 7 March 1997.

41. ilva, L.G.; Zucchi, R.A.; Silveira, Neto, S. Levantamento de moscas-das-frutas (Diptera: Tephritidae) em vários hospedeiros no Estado do Amazonas, Piracicaba, São Paulo, Brazil (in Portuguese). In Proceedings the 14th Brazilian Congress of Entomology, Piracicaba, São Paulo, Brazil, 29 January 1993.

42. Nicácio, J.N.; Uchôa, M.A.; Faccenda, O.; Guimarães, J.A.; Marinho. C.F. Native larval parasitoids (Hymenoptera) of frugivorous Tephritoidea (Diptera) in South Pantanal Region, Brazil. Flo. Entomol. 2011, 94, 407-419.

43. Alvarenga, C.D.; Matrangolo, C.A.R.; Lopes, G.N.; Silva, M.A.; Lopes, E.N.; Alves, D.A.; Nascimento, A.S.; Zucchi, R.A. Moscas-das-frutas (Diptera: Tephritidae) e seus parasitóides em plantas hospedeiras de três municípios do norte do estado de Minas Gerais (in Portuguese). Arq. Inst. Biol. 2009, 76, 195-204.

44. Ohashi, O.S.; Dohara, R.; Zucchi, R.A.; Canal, D.N.A. Ocorrência de Anastrepha obliqua (Macquart, 1835) (Dip.: Tephritidae) em acerola Malpighia punicifolia L., no Estado do Pará (in Portuguese). An. Soc. Entomol. Brasil. 1997, 26, 389-390.

45. Zucchi, R.A.; Canal, D.N.A.; Padua, L.E.M.; Silva, P.R.R.; Silva, P.H.S. Primeiro registro de Anastrepha spp. (Dip., Tephritidae), seus hospedeiros e parasitoides (Hym., Braconidae) no Estado do Piauí, (in Portuguese). In Proceedings the 15th Brazilian Congress of Entomology, Caxambu, Minas Gerais, Brazil, 17 March 1995.

46. Aguiar-Menezes, E.L.; Menezes, E.B. Natural occurrence of parasitoid of Anastrepha spp. Schiner, 1868 (Diptera: Tephritidae) in different host plants, in Itaguati (RJ), Brazil. Biol. Contr. 1997, 8, 1-6.

47. Penteado-Dias, A.M. Parasitismo de Tephritidae (Diptera) por Opiinae (Hymenoptera, Braconidae) na região de São Carlos, SP, (in Portuguese). In Proceedings the 11st Brazilian Congress of Entomology, Campinas, São Paulo, Brazil, 15 June 1987.

48. Souza Filho, M.F.; Raga, A.; Zucchi, R.A. Evaluacion de la incidência de Anastrepha obliqua y Ceratitis capitata em carambola (Averrhoa carambola) em el Estado de São Paulo, Brasil, Viña del Mar, Chile (in Portuguese). In Proceedings of the 2nd Meeting of the Working Group on Fruit Flies of the Western Hemisphere, Viña del Mar, Chile, 8 November 1996.

49. Sugayama, R.L.; Canal, D.N.A. Opiinae parasitoids (Braconidae) associated with fruit flies (Tephritidae) in Bauru, SP. In Proceedings of the 5th Brazilian Symposium of Biological Control, Foz do Iguaçu, Paraná, Brazil, 14 June 1996. 
50. Marinho, C.F.; Souza-Filho, M.F.; Raga, A.; Zucchi, R.A. Parasitóides (Hymenoptera: Braconidae) de moscas-das-frutas (Diptera: Tephritidae) no estado de São Paulo: plantas associadas e parasitismo (in Portuguese). Neotrop. Entomol. 2009, 38, 321-326.

51. Canal, D.N.A.; Uchôa, F.; Zucchi, R.A. Novo registro de Doryctobracon fluminensis (Lima, 1938)(Hym., Braconidae) parasitoide de moscas-das-frutas (Dip., Tephritidae), (in Portuguese). In Proceedings the 5th Brazilian Symposium of Biological Control, Foz do Iguaçu, Paraná, Brazil, 14 June 1996.

52. Lima, A.C. Vespas parasitas de moscas de frutas (Hymenoptera: Braconidae) (in Portuguese). O Campo. 1938, 9, 69-72.

53. Weld, L.H. New Eucoilinae (Hymenoptera: Cynipoidea). Proc. Ent. Soc. Wash. 1951, 53, 223-226.

54. Borgmeier, T. Sobre alguns cynipideos parasiticos e cecidógenos do Brasil (Hymenoptera: Cynipidae) (in Portuguese). Arq. Inst. Biol. Veg. 1935, 2, 97-124.

55. Marchiori, C.H.;Penteado-Dias, A.M. Trichopria anastrephae (Hymenoptera: Diapriidae), parasitoide de Diptera, coletadas em área de mata nativa e pastagem em Itumbiara, Goiás, Brasil (in Portuguese). Arq. Inst. Biol. 2001, 68, 123-124.

56. Silva, C.G.; Marchiori, C.H.; Fonseca, A.R.;Torres, L.C. Himenópteros parasitóides de larvas de Anastrepha spp. em frutos de carambola (Averrhoa carambola L.) na região de Divinópolis, Minas Gerais, Brasil (in Portuguese). Ciênc. e Agrotec. 2003, 27, 1264-1267.

57. Lima, A.C. Alguns parasitos de mosca das frutas (in Portuguese). Anais Acad. Bras. Cienc. 1940, 12, 17-20.

58. Aguiar-Menezes, E.; Menezes, E.B.; Silva, P.S.; Bittar, A.C.; Cassino, P.C. Native hymenopteran parasitoids associated with Anastrepha spp. (Diptera: Tephritidae) in Seropedica city, Rio de Janeiro Brazil. Flo. Entomol. 2001, 84, 706-711.

59. Ashmead, W.H. Some new genera in the Cynipoidea. Proc. Entomol. Soc. Wash. 1903, 5, 221-223.

60. Leonel, F.L., Jr.; Zucchi, R.A.; Canal, D.N.A. Parasitismo de moscas-das-frutas (Diptera: Tephritidae) por Braconidae (Hymenoptera) em duas localidades do Estado de São Paulo. An. Soc. Entomol. Brasil. 1996, 25, 199-206.

61. Carvalho, R. da S.; Nascimento, A.S.; Matrangolo, W.J.R. Controle biológico. In Moscas-dasfrutas de importância econômica no Brasil. Conhecimento básico e aplicado (in Portuguese); Malavasi, A., Zucchi, R.A., Eds.; Holos: Ribeirão Preto, Brazil, 2000; pp. 113-117.

62. Carvalho, R.S. Biocontrole de moscas-das-frutas: histórico, conceitos e estratégias (in Portuguese). Bahia Agrícola 2006, 7, 14-17.

63. Costa, V.A.; Araújo, E.L.; Guimarães, J.A.; Nascimento, A.S.; Lasalle, J. Redescoberta de Tetrastichus giffardianus (Hymenoptera: Eulophidae) após 60 anos da sua introdução no Brasil (in Portuguese). Arq. Inst. Biol. 2005, 72, 539-541.

64. Leal, M.R.; Aguiar-Menezes, E.L.; Filho, M.L.; Ribeiro, J.C.R.; Menezes, E.B. Capacidade de sobrevivência e dispersão de Diachasmimorpha longicaudata um parasitoide exótico de larva de moscas-das-frutas (in Portuguese); Embrapa: Rio de Janeiro, Brazil, 2008. 
65. Matrangolo, W.J.R.; Nascimento, A.S.; Carvalho, R.S.; Melo, E.D.; Jesus, M. Parasitóides de moscas-das-frutas (Diptera: Tephritidae) associados a fruteiras tropicais (in Portuguese). An. Soc. Entomol. Brasil. 1998, 27, 593-603.

66. Carvalho, R.S. Avaliação das liberações inoculativas do parasitoide exótico Diachasmimorpha longicaudata (Ashmead)(Hymenoptera: Braconidae) em pomar diversificado em Conceição de Almeida, BA (in Portuguese). Neotropic. Entomol. 2005, 34, 799-805.

67. Carvalho, R.S. Estudos de laboratório e de campo com o parasitóide exótico Diachasmimorpha longicaudata (Ashmead) (Hymenoptera: Braconidae) no Brasil (in Portuguese). Ph.D. thesis, Instituto de Biociências, Universidade de São Paulo, São Paulo, Brazil, 2003.

68. Corsato, C.D.A. Moscas-das-frutas (Diptera: Tephritidae) em pomares de goiaba no norte de Minas Gerais: Biodiversidade, Parasitoides e Controle Biológico (in Portuguese). Ph.D. thesis, Escola Superior de Agricultura "Luiz de Queiroz", Universidade de São Paulo, Piracicaba, São Paulo, 2004.

69. Alvarenga, C.D.; Brito, E.S.; Lopes, E.N.; Silva, M.A.; Alves, D.A.; Matrangolo, C.R.; Zucchi, R.A. Introdução e recuperação do parasitoide exótico Diachasmimorpha longicaudata (Asmead) (Hymenoptera: Braconidae) em pomares comerciais de goiaba no norte de Minas Gerais (in Portuguese). Neotrop. Entomol. 2005, 34, 133-136.

70. Alves, V.E. da S. Dinâmica populacional de moscas-das-frutas (Diptera: Tephritidae) antes e após a liberação de Diachasmimorpha longicaudata (Hymenoptera: Braconidae) em área de intersecção de pomar cítrico e mata secundária (in Portuguese). Ph.D. thesis, Faculdade de Ciências Agronômicas São Paulo, Universidade Estadual Paulista, São Paulo, Brazil, 2010.

71. Cancino, J.L. Biologia y comportamiento de Diachasmimorpha longicaudata, parasitoide de mosca de la fruta. In Curso Regional sobre Moscas de la Fruta y su Control com Énfasis em la Técnica del Inseto Estéril (in Portuguese); Anais: Tapachula, Chiapas, 1997; pp. 89-96.

72. Purcell, M.F.; Stark, J.D.; Messing, R.H. Insecticide effect on three tephritid fruit flies and associated braconid parasitoids in Hawaii. J. Econ. Entomol. 1994, 87, 1455-1462.

73. Walder, J.M.M.; Costa, M.L.Z.; Lopes L.A. Alguns aspectos biológicos do parasitoide Diachasmimorpha longicaudata (Ashmead) (Hymenoptera: Braconidae) criado sobre larvas de Ceratitis capitata (Wied. 1824) (Diptera: Tephritidae) (in Portuguese). In Proceedings of the 16th Brazilian Congress of Entomology, Salvador, Bahia, Brazil, 14 June 1997.

74. Cancino, J.; Ruiz, L.; Montoya, P.; Harris, E. Biological atributes of three introduced parasitoids as natural enemies of fruit flies, genus Anastrepha (Diptera: Tephritidae). J. Appl. Entomol. 2009, $133,181-188$.

75. Sivinski, J. The Influence of host fruit morphology on parasitization rates in the Caribbean fruit fly, Anastrepha suspensa. Entomophaga 1991, 36, 447-454.

76. Baranowski, H.R.; Glenn, H.; Sivinski, J. Biological control of the caribean fruit fly (Dip.: Tephritidae). Flo. Entomol. 1993, 76, 245-250.

77. Burns, R.E.; Diaz, J.D.; Holler, T.C. Inundative release of the parasitoid Diachasmimorpha longicaudata for the control of the Caribbean fruit fly, Anastrepha suspensa. In A World Assessment of Their Biology and Management; Mcpheron, B.A., Steck, G.J., Eds.; St. Lucie Press: Delray Beach, FL, USA, 1996; pp. 377-381. 
78. Sivinski, J.; Calkins, C.; Baranowski, R.; Harris, D.; Brambila, J. Suppression of a Caribbean fruit fly Anastrepha suspensa (Loew) Diptera: Tephritidae) population through augmented releases of the parasitoid Diachasmimorpha longicaudata (Ashmead) (Hymenoptera: Braconidae). Biol. Contr. 1996, 6, 177-185.

79. Montoya, P.; Liedo, P.; Benrey, B.; Cancino, J.; Barrera, J.F.; Sivinski, J.; Aluja, M. Biological Control of Anastrepha spp. (Diptera: Tephritidae) in mango orchards through augmentative releases of Diachasmimorpha longicaudata (Ashmead) (Hymenoptera: Braconidae). Biol. Contr. 2000, 18, 216-224.

80. Costa, M.L.Z.; Costa, K.Z.; Faggioni, K.M.; Sanches, P.A; Morelli, R.; Walder; J.M.M. Domesticação do parasitoide Doryctobracon areolatus (Hymenoptera: Braconidae) em larvas de Anastrepha fraterculus (Diptera: Tephritidae) em condições artificiais (in Portuguese). In Proceedings of 12th Brazilian Symposium of Biological Control, Piracicaba, São Paulo, Brazil, 2011.

81. Walder, J.M.M. Produção de moscas-das-frutas e seus inimigos naturais - Associação de moscas estéreis e controle biológico. In Controle Biológico no Brasil - Parasitóides e Predadores (in Portuguese); Parra, J.R.P., Botelho, P.S.M., Correa-Ferreira, B.S.; Bento, J.M.S., Eds.; Editora Manole: São Paulo, Brazil, 2002; pp. 181-190.

82. Costa, M.L.Z.; Costa, K.Z.; Faggioni, K.M.; Sanches, P.A; Morelli, R.; Walder, J.M.M. Criação massal do parasitóide Diachasmimorpha longicaudata (Hymenoptera:Braconidae) criado em larvas de Ceratitis capitata (Diptera:Tephritidae) Piracicaba (in Portuguese). In Proceedings of 12th Brazilian Symposium of Biological Control, São Paulo, Brazil, 2011.

83. Zenil, M.; Liedo, P.; Williams, T.; Valle, J.; Cancino, J.; Montoya, P. Reproductive biology of Fopius arisanus (Hymenoptera: Braconidae) on Ceratitis capitata and Anastrepha spp. (Diptera: Tephritidae). Biol. Contr. 2004, 29, 169-178.

84. Purcell, M.; Herr, J.C.; Messing, R.H.; Wong, T.T.Y. Interactions between augmentatively relesead Diachasmimorpha longicaudata (Hymenoptera: Braconidae) and a complex of opiinae parasitoid in a commercial guava orchard. Biocontrol Sci. Technol. 1998, 8, 139-151.

85. Wang, X.G.; Messing, R.H. Newly imported larval parasitoids pose minimal competitive risk to extant egg-larval parasitoid of tephritid fruit flies in Hawaii. Bull. Entomol. Res. 2002, 92, $423-429$.

86. Wang, X.G.; Messing, R.H.; Bautista, R.C. Competitive superiority of early acting species: A case study of opiinae fruit fly parasitoids. Biocontrol Sci. Technol. 2003, 13, 391-402.

87. Carvalho, R.S.; Nascimento, A.S. Criação e utilização de Diachasmimorpha longicaudata para controle biológico de moscas-das-frutas. In Controle Biológico no Brasil - Parasitóides e Predadores (in Portuguese); Parra, J.R.P., Botelho, P.S.M., Correa-Ferreira, B.S., Bento, J.M.S., Eds.; Editora Manole: São Paulo, Brazil, 2002; pp. 65-179.

(C) 2013 by the authors; licensee MDPI, Basel, Switzerland. This article is an open access article distributed under the terms and conditions of the Creative Commons Attribution license (http://creativecommons.org/licenses/by/3.0/). 